\title{
Violence and repair: The practice and challenges of non- State armed groups engaging in reparations
}

\section{Luke Moffett*}

Luke Moffett is a Senior Law Lecturer at Queen's University Belfast. He is Principal Investigator on the Arts and Humanities Research Council-funded "Reparations, Responsibility and Victimhood in Transitional Societies" project. As an expert on transitional justice and international humanitarian law he works with a number of victim groups, governments and ex-fighters on reparations and dealing with the past in post-conflict societies.

\section{Abstract}

Atrocities by non-State armed groups (NSAGs) often capture international attention, but efforts to repair the harm they have caused are often overlooked. This article traces out some of the practices and tensions in NSAGs making reparations during wartime and in post-conflict transitions. It argues that engaging in reparations for acts committed by NSAGs can not only encourage greater compliance with international

* My sincerest thanks to Katharine Fortin, Kieran McEvoy, Cheryl Lawther and Kevin Hearty for their comments on this article. This article was presented as a paper at the Socio-Legal Studies Association Conference in Leeds in 2019 and at the Geneva Academy in June 2019 as part of a workshop co-organized with Clara Sandoval, Thomas Unger, Frank Haldemann, Annyssa Bellal and Marco Sassòli. I am grateful to the participants for their feedback at these events, as well as the constructive comments of the anonymous peer reviewers and editorial team. The fieldwork discussed in this article draws from the Arts and Humanities Research Council-funded "Reparations, Responsibility and Victimhood in Transitional Societies" project (AH/P006965/1).

(c) The Author(s), 2021. Published by Cambridge University Press on behalf of the ICRC. This is an Open Access article, distributed under the terms of the Creative Commons Attribution licence (https://creativecommons.org/licenses/by/4.0/), which permits unrestricted re-use, distribution, 
humanitarian law but also build support amongst civilian populations during armed conflict and facilitate ex-fighter reintegration at the end of hostilities. Drawing from interviews with a number of armed groups, the article also suggests that engaging with the armed group's organization rather than just individuals themselves can be an effective way to collectively mobilize a group's motivation and capacity to deliver on reparations, including recovery of disappeared persons, restitution of property and apologies. As such, this article seeks to contribute to a deeper understanding of reparation practices by NSAGs in order to see how reparations can be mediated and a hierarchy of reparation obligations developed.

Keywords: non-State armed groups, reparations, rebel governance, transitional justice.

Under international law, it is well recognized that non-State armed groups (NSAGs) have international humanitarian law (IHL) obligations when they are parties to armed conflict. The question of whether they also have human rights obligations has received increasing attention. ${ }^{1}$ Despite this, recognition of their obligations of cessation and remedy have received less consideration and remain debateable. There have been claims that reparations ${ }^{2}$ by NSAGs are a non-starter, in that there are "virtually no instances" of them, ${ }^{3}$ victims are unable to claim them, ${ }^{4}$ or it is unnecessary to seek redress from the perpetrators. ${ }^{5}$

Despite this, NSAGs do make reparations during wartime and in postconflict societies. Overlooking this practice disregards the purpose of reparations as a form of justice and a political project, which acknowledges and alleviates as far as possible victims' harm by a responsible actor and can allow the reestablishment of social and moral relations between individuals and institutions. ${ }^{6}$ Neglecting reparations by NSAGs could prevent their victims from accessing an effective remedy, such as the location of the remains of the disappeared.?

1 See Tilman Rodenhäuser, Organizing Rebellion: Non-State Armed Groups under International Humanitarian Law, Human Rights Law, and International Criminal Law, Oxford University Press, Oxford, 2018, pp. 154-157; Ben Saul, "Enhancing Civilian Protection by Engaging Non-State Armed Groups under International Humanitarian Law", Journal of Conflict \& Security Law, Vol. 22, No. 1, 2017, p. 41.

2 Reparations refer to measures made by armed groups to make good on a wrong committed by them or some form of suffering for which they are responsible.

3 Emanuela-Chiara Gillard, "Reparation for Violations of International Humanitarian Law", International Review of the Red Cross, Vol. 85, No. 851, 2003, p. 534.

4 Cecily Rose, "An Emerging Norm: The Duty of States to Provide Reparations for Human Rights Violations by Non-State Actors", Hastings International and Comparative Law Review, Vol. 33, No. 2, 2010, p. 309.

5 Maria José Guembe and Helena Olea, "No Justice, No Peace: Discussion of a Legal Framework regarding the Demobilization of Non-State Armed Groups in Colombia", in Naomu Roht-Arriaza and Javier Mariezcurrena (eds), Transitional Justice in the Twenty-first Century, Cambridge University Press, Cambridge, 2006, p. 136.

6 See Pablo de Greiff, "Justice and Reparations", in P. de Greiff (ed.), Handbook of Reparations, Oxford University Press, Oxford, 2006.

7 Ron Dudai, “Closing the Gap: Symbolic Reparations and Armed Groups”, International Review of the Red Cross, Vol. 93, No. 883, 2011, p. 785. 
Accordingly, reparations not only benefit victims, but this article argues that they can also be beneficial to NSAGs in managing their relations with civilians during conflict, their political constituencies and their reintegration at the end of hostilities. ${ }^{8}$ Reparations can help NSAGs to improve their image and recalibrate their wrongdoings as not simply sources of shame and humiliation, but as an opportunity to make amends.

Importantly, NSAGs making reparations for their violations and acknowledging their wrongdoing could be a pragmatic way for them to enhance their respect for and internalization of humanitarian norms. ${ }^{9}$ Approaching the issue from a practice perspective, seeing through the eyes of armed groups and drawing from their ideology, world view or customs may be conducive to improving their ownership of and buy-in to humanitarian law. ${ }^{10}$ Ignoring NSAG compliance with humanitarian law through focusing only on States risks the legitimacy of humanitarian law mechanisms by making them appear to be Statebiased. ${ }^{11}$ This article positions the discussion of reparations within the increasing literature on civilians' agency and their relationship with armed groups during conflict, rebel governance and transitional justice.

Despite the growing attention to NSAGs, there has been little analysis aimed at developing a theoretical or pragmatic approach to link their legal responsibility under IHL, or arguably under human rights law, with secondary rules of reparations. ${ }^{12}$ Indeed, there has been "no concentrated effort to develop either a normative doctrine or practical modalities to enable armed groups to provide measures of reparations to their victims". ${ }^{13}$ This article provides some content to fill these gaps, not just in abstract terms, but by examining their practice in making reparations during and post-conflict. It will draw from interviews with sixteen NSAGs from nine countries, ${ }^{14}$ the broader academic literature, and primary materials including codes of conduct, internal policies and communiqués.

The article begins by briefly outlining the possible legal basis of obligations of NSAGs to make reparations under IHL and human rights law. It finds that there are limitations in speaking of secondary obligations for NSAGs to make reparations despite being responsible for violations. As a result, it suggests that there could be a

8 NSAGs may make amends to enemy fighters, especially at the end of hostilities, but this may be difficult, as it requires them to acknowledge their responsibility and the victimhood of their enemy. See "Colombian Ex-Farc Rebels 'Ashamed' of Kidnappings”, BBC News, 15 September 2020, available at: www.bbc.co.uk/ news/world-latin-america-54160284 (all internet references were accessed in July 2021).

9 B. Saul, above note 1, p. 64 .

10 Katharine Fortin, "Armed Groups and Procedural Accountability: A Roadmap for Further Thought", Yearbook of International Humanitarian Law, Vol. 19, 2016, p. 158.

11 Pascal Bongard and Jonathan Somer, "Monitoring Armed Non-State Actor Compliance with Humanitarian Norms: A Look at International Mechanisms and the Geneva Call Deed of Commitment", International Review of the Red Cross, Vol. 93, No. 883, 2011, p. 675.

12 See Laura Ínigo Álvarez, Towards a Regime of Responsibility of Armed Groups in International Law, Intersentia, Cambridge, 2020.

13 Ron Dudai and Kieran McEvoy, "Thinking Critically about Armed Groups and Human Rights Praxis", Journal of Human Rights Practice, Vol. 4, No. 1, 2012, p. 18.

14 Interviewees came from Nepal, Ethiopia, Peru, Colombia, Lebanon, Guatemala, Uganda, Northern Ireland and South Sudan, and included foot soldiers and senior commanders involved in peace negotiations, men and women, and indigenous and former child soldiers. 
hierarchy of reparations based on the capacity of the group and to see such measures as a mediated solution rather than just a legal obligation. The article then explores the literature around violence and restraint, which provides a more complex picture of relationships between NSAGs and civilians during conflict. The second section discusses the incentives of NSAGs to make reparations during conflict on ideological grounds, for the purposes of maintaining or improving governance, or to restore the image of the group. This discussion also recognizes that there are a number of challenges, risks and costs in practice. The third section critically reflects on the practice of NSAGs making reparations in post-conflict societies, where hostilities have ended and where there may be more political space to speak of reparations. The article concludes by discussing how to move forward on reparations by armed groups and to build ownership of NSAGs in making amends for violence.

\section{Reparations, non-State armed groups and international law}

Legal analysis on NSAGs and reparations has concentrated on such actors' responsibility and obligations under international law. ${ }^{15}$ A detailed examination of the law and NSAGs is beyond the scope of this article. ${ }^{16}$ Instead, the article intends to take a different perspective by drawing on interviews with NSAGs in order to make a unique contribution to their role on reparations. This bottom-up perspective contrasts with the international law position, which remains reluctant to bestow legitimacy on such groups due to the risks of justifying their violence or undermining the authority of the State; this approach prevents their inclusion into the international legal order. ${ }^{17}$ Yet non-international armed conflicts have been the main form of armed conflict since the Second World War. ${ }^{18}$ Neglecting the responsibility of NSAGs is potentially "dangerous". ${ }^{19}$ NSAGs can project power, control territory, provide services and conduct their own courts, which can make them appear like a State within their own jurisdiction. This means that some NSAGs have governed millions of individuals, whereas others have been embedded in communities for years or even decades.

15 See Liesbeth Zegveld, The Accountability of Armed Organised Groups in International Law, Cambridge University Press, Cambridge, 2002.

16 See the article by Olivia Herman in this issue of the Review.

17 Daragh Murray, "Engaging Armed Groups through the Development of Human Rights Obligations: Incorporating Practice, Motivation and Ideology to Promote Compliance with International Law", Yearbook of International Humanitarian Law, Vol. 19, 2016, p. 124.

18 In the city of Misrata, Libya, in 2011, 236 armed groups were operating at one point. See Brian McQuinn, After the Fall: Libya's Evolving Armed Groups, Small Arms Survey Working Paper No. 12, 2012, p. 13. In 2018 there were fifty-one non-international armed conflicts, seven international armed conflicts and eleven belligerent occupations globally: see Annyssa Bellal, The War Report: Armed Conflicts in 2018, Geneva Academy of International Humanitarian Law and Human Rights (Geneva Academy), Geneva, 2019, pp. 32-34. See also ICRC, ICRC Engagement with Non-State Armed Groups: Why, How, for What Purpose, and Other Salient Issues, ICRC Position Paper, Geneva, March 2021.

19 Andrew Clapham, The Rights and Responsibilities of Armed Non-State Actors: The Legal Landscape and Issues Surrounding Engagement, Geneva Academy, Geneva, 2010, p. 3. 
The language of NSAGs' legal obligations assumes that these entities are coherent actors for conceptual and practical purposes. However, their heterogeneity, ambiguity and even transience of capacity and existence besets this frame of analysis. NSAGs, rebels and insurgents remain undefined in international law. ${ }^{20}$ NSAGs can include armed liberation fighters holding vast swathes of territory, paramilitary or community-based defence organizations, small gangs or mafias controlling a few blocks in a city, and even mercenary groups. ${ }^{21}$ Rodenhäuser suggests that NSAGs are now "less structured, fragmented, or operating in loose coalitions and with diverse agendas". ${ }^{22}$ Indeed, the heterogeneous nature and multitude of armed groups makes a one-size-fits-all approach under international law problematic. ${ }^{23}$ In human rights law, NSAGs cannot become parties to human rights conventions. ${ }^{24}$ Their human rights obligations remain contested; practice suggests that certain ones exist in the exceptional circumstances where such groups control territory and fulfil State-like or government-like functions. ${ }^{25}$

For States, obligations to make reparations for the conduct of NSAGs only arise where such conduct is attributable to the State. Moreover, if an NSAG becomes the new government of the State, its past violations now become the responsibility of the State. While this rule was crafted with accountability in mind, ${ }^{26}$ it is unlikely to include situations where the armed group engages in a power-sharing arrangement or takes power through democratic elections. ${ }^{27}$ Before the International Criminal Court, individual members of NSAGs can be held criminally responsible for

20 Jean D'Aspremont, "Rebellion and State Responsibility: Wrongdoing by Democratically Elected Insurgents”, International and Comparative Law Quarterly, Vol. 58, No. 2, 2009, p. 433; L. Zegveld, above note 15 , p. 134 .

21 Annyssa Bellal, "Non-State Armed Groups in Transitional Justice Processes: Adapting to New Realities of Conflict", in Roger Duthie and Paul Seils (eds), Justice Mosaics: How Context Shapes Transitional Justice in Fractured Societies, International Center for Transitional Justice, New York, 2017, p. 237.

22 T. Rodenhäuser, above note 1, p. 1.

23 Under Article 3 common to the Geneva Conventions, armed groups would have to satisfy the condition of being under an organized command and the conflict reaching a sufficient intensity without the requirement for territorial control. See International Criminal Tribunal for the Former Yugoslavia, Prosecutor v. Tadić, Case No. IT-94-1-AR72, Decision on the Defence Motion for Interlocutory Appeal on Jurisdiction, 2 October 1995, para. 70, and Case No. IT-94-1, Judgment, 7 July 1997, para. 562; International Criminal Court, Prosecutor v. Lubanga, Case No. ICC-01/04-01/06-2842, Judgment, 14 March 2012, para. 538. Article 1 of Additional Protocol II also sets out its material scope of application as being those circumstances where an armed group exercises control over territory and is able "to carry out sustained and concerted military operations and to implement this Protocol".

24 See Optional Protocol to the Convention on the Rights of the Child on the Involvement of Children in Armed Conflict, 2000, Art. 4; Convention for the Protection and Assistance of Internally Displaced Persons in Africa, 2009; Committee on the Elimination of Discrimination against Women, General Recommendation No. 30, "Women in Conflict Prevention, Conflict and Post-Conflict Situations", 2013; African Commission on Human and People's Rights, General Comment No. 4, “The Right to Redress for Victims of Torture and Other Cruel, Inhuman or Degrading Punishment or Treatment (Article 5)", 2017.

25 Alexander Breitegger, "The Legal Framework Applicable to Insecurity and Violence Affecting the Delivery of Health Care in Armed Conflicts and Other Emergencies", International Review of the Red Cross, Vol. 95, No. 889, 2014, pp. 100-104. See also the article by Olivia Herman in this issue of the Review.

26 International Law Commission, Draft Articles on the Responsibility of States for Internationally Wrongful Acts, 2001, Art. 10, p. 51; J. D’Aspremont, above note 20, pp. 438-439.

27 See Luke Moffett, "Beyond Attribution: Responsibility of Armed Non-State Actors for Reparations in Northern Ireland, Colombia and Uganda”, in Noemi Gal-Or, Cedric Ryngaert and Math Noortmann 
international crimes and held liable for reparations. ${ }^{28}$ However, they are often too indigent to provide reparations. ${ }^{29}$ Accordingly, international law continues to inadequately articulate the appropriate parameters for the responsibility of NSAGs for reparations. ${ }^{30}$

NSAGs' obligations to make reparations under international law remain tenuous. IHL provides for a limited scope of reparations of only compensation for violations during international armed conflicts under Article 91 of Additional Protocol I, which does not apply to NSAGs and non-international armed conflicts. Moreover, IHL is silent on an individual's right to reparation, enforcement mechanisms against States, and the applicability of compensation rules for non-international armed conflicts. ${ }^{31}$ This may be slowly changing. ${ }^{32}$ Human rights law more clearly articulates States' obligation to provide reparations to all victims of gross violations of human rights, in light of the principle of subsidiarity of the State to ensure an effective remedy, with only softlaw declarations for NSAGs to have similar obligations. For instance, the 2005 UN Basic Principles speak of the liability of a "person, legal entity or other entity" to provide reparations to victims or to indemnify the State where it has already done so. ${ }^{33}$ Indeed, the issue seems a circular one that situates the analysis from a State-centric perspective, rather than being about ensuring an effective remedy for victims. ${ }^{34}$ Commissions of inquiry increasingly call upon NSAGs to make reparations for such violations through State programmes. ${ }^{35}$ Indeed, one commander of the Revolutionary Armed Forces of Colombia-People's Army (Fuerzas Armadas Revolucionarias de Colombia-Ejército del Pueblo, FARC-EP) argued this point because, during war, violence "got out of the hands of many

(eds), Responsibilities of the Non-State Actor in Armed Conflict and the Market Place, Brill, Leiden and Boston, MA, 2015.

28 Rome Statute of the International Criminal Court, 1998 (Rome Statute), Art. 75(2).

29 See Luke Moffett and Clara Sandoval, "Tilting at Windmills: Reparations and the International Criminal Court", Leiden Journal of International Law, 2021 (forthcoming).

30 Agnes Callamard, "Towards International Human Rights Law Applied to Armed Groups", Netherlands Quarterly of Human Rights, Vol. 37, No. 1, 2019, p. 100.

31 Additional Protocol I, Art. 91, building upon Hague Convention IV, Art. 3. See Liesbeth Zegveld, "Remedies for Victims of Violations of International Humanitarian Law", International Review of the Red Cross, Vol. 85, No. 851, 2003, p. 507.

32 See Lawrence Hill-Cawthorne, "Rights under International Humanitarian Law", European Journal of International Law, Vol. 28, No. 4, 2017, pp. 1211-1212; International Law Association Committee on Reparation for Victims of Armed Conflict, Res. 2, "Declaration of International Law Principles on Reparation for Victims of Armed Conflict (Substantive Issues)", 2010, Art. 5(2).

33 See UNGA Res. 60/147, "Basic Principles and Guidelines on the Right to a Remedy and Reparation for Victims of Gross Violations of International Human Rights Law and Serious Violations of International Humanitarian Law", UN Doc. A/RES/60/147, 16 December 2005, Principles 15-16; Clara Sandoval, "International Human Rights Adjudication, Subsidiarity and Reparation for Victims of Armed Conflict", in Cristián Correa, Shuichi Furuya and Clara Sandoval, Reparation for Victims of Armed Conflict, Max Planck Trialogues, Cambridge University Press, Cambridge, 2020, p. 182; and see the article by Olivia Herman in this issue of the Review.

34 A. Clapham, above note 19, p. 24.

35 Human Rights Council, Report of the Independent International Commission of Inquiry on the Syrian Arab Republic, UN Doc. A/HRC/42/51, 15 August 2019, p. 19; Human Rights Council, Situation of Human Rights in Yemen: Report of the Detailed Findings of the Group of Eminent International and Regional Experts on Yemen, UN Doc. A/HRC/42/CRP.1, 3 September 2019, para. 868 and p. 225. 
people and ... things happened that never should have happened. ... [I]f someone killed another person then that money has to be from that person; that doesn't make sense. The State will always be primarily responsible for such reparation." 36 Simply holding NSAGs responsible for reparations for all violations in the same way as a State overlooks the "idiosyncratic" nature of each group. ${ }^{37}$ A hierarchy of reparation obligations for NSAGs may better fit their capacity, while avoiding minimal compliance through voluntary contributions would also complement more adequately funded and supported State-run reparation programmes.

Instead of proliferating the legal regimes as they currently are and trying to making NSAGs fit them, it may be more productive to consider the practice of armed groups in order to help discern a hierarchy of reparation obligations that can slot into a State domestic reparation programme. ${ }^{38}$ Sassòli suggests a sliding scale of obligations, reflecting the organization of the armed group and the stability of its control over territory, corresponding with an increasing applicability of IHL. ${ }^{39}$ Mastorodimos suggests different layers of human rights obligations based on an NSAG's capacity. ${ }^{40}$ In light of both of these arguments, a hierarchy of secondary obligations for reparations could be explored for NSAGs based on their organization, control of territory and capacity, ranging from medical rehabilitation to compensation or memorials. These would not displace the State's obligation to establish a reparation programme. Fortin proposes that obligations could be shared between two duty holders, such as a State and an NSAG, based on their "capabilities and immediate relevance", which could reflect the limited capacity of NSAGs to provide reparations. ${ }^{41}$ We should be cautious in crafting reparation obligations for NSAGs in terms of creating institutional isomorphism by comparing them to State obligations and requiring NSAGs to provide "full" reparations. ${ }^{42}$ Alternative accountability mechanisms may be more effective in getting an armed group to internalize norms through more "tailormade" solutions that focus on "social interaction", such as the Geneva Call Deeds

36 Interview with female FARC-EP commander, Bogotá, 27 February 2019.

37 Jann K. Kleffner, "The Collective Accountability of Organized Armed Groups for System Crimes", in Harmen van derWilt, André Nollkaemper, M. M. Dolman and Jann K. Kleffner (eds), System Criminality in International Law, Cambridge University Press, Cambridge, 2009, p. 261.

38 Ezequiel Heffes and Brian Frenkel, "The International Responsibility of Non-State Armed Groups: In Search of the Applicable Rules", Goettingen Journal of International Law, Vol. 8, No. 1, 2017, p. 69.

39 Marco Sassòli, "Introducing a Sliding-Scale of Obligations to Address the Fundamental Inequality between Armed Groups and States?", International Review of the Red Cross, Vol. 93, No. 882, 2011, p. 430. Bellal and Rodenhäuser argue that the greater the capacity, the greater the expectation to fulfil human rights obligations in order to avoid protection gaps. Annyssa Bellal, "Establishing the Direct Responsibility of Non-State Armed Groups for Violations of International Norms: Issues of Attribution", in N. Gal-Or, C. Ryngaert and M. Noortmann (eds), above note 27, pp. 308-309; and T. Rodenhäuser, above note 1, pp. 148-149.

40 Konstantinos Mastorodimos, Armed Non-State Actors in International Humanitarian and Human Rights Law, Ashgate, Farnham, 2016, p. 185.

41 Katharine Fortin, The Accountability of Armed Groups Under Human Rights Law, Oxford University Press, Oxford, 2017, p. 67.

42 Paloma Blázquez Rodríguez, "Does an Armed Group Have an Obligation to Provide Reparations to Its Victims?", in James Summers and Alex Gough (eds), Non-State Actors and International Obligations, Brill, Leiden, 2018, p. 424. 
of Commitment. ${ }^{43}$ This is not to suggest that such measures taken by NSAGs have a lesser value than those provided to State victims, but we have to recognize that they will be more limited. Nevertheless, NSAG reparations can have a particular benefit or "added value", such as the return of a family home, guarantees of safe passage for a displaced family or public acknowledgement that a person killed was not an informer.

The value in calling such remedial measures "reparations" is that it provides a moral baseline and normative content of what they should include, such as victim participation, non-discrimination and appropriate forms. Victim participation ensures that those most affected can have input to effectively shape the appropriate forms of reparations. Non-discrimination aims to mitigate further secondary harms or exclusion of certain groups or people from reparations. Appropriate forms of reparation refer to measures that can contribute "as far as possible" 44 to remedying victims' suffering. This offers an interpretative tool to guide the progressive development of NSAGs' responsibility in international law and to ensure that reparations are adequate and effective in remedying victims' harm. ${ }^{45}$ Moreover, such measures are a way to end impunity for violations by asking NSAGs to engage in self-reflection on the harm they have caused and the human cost of their actions. To an extent this may seem utopian, but armed groups instrumentally use restraint and violence. It also reflects the increasing practice of armed actors to provide reparations in conflict situations in order to alleviate victims' suffering. ${ }^{46}$ A number of armed groups we spoke to recognized and practiced reparation in order to "get closer to the civilian population", ${ }^{77}$ with others having a "culture of compensation" as something "for our own benefit as people need to support the war effort". 48

Relying only on international law to delimit the scope of violations for reparations when dealing with NSAGs is also problematic as it neglects the smaller, but impactful, harms that civilians suffer. For instance, one FARC-EP commander recalled how his company of 120 fighters moved through a farmer's field and picked some of the berries along the way. While each fighter only took a handful, for the farmer it amounted to a few kilos of produce. To avoid

43 K. Fortin, above note 10, pp. 175-176. Geneva Call's four Deeds of Commitment cover landmines and explosive weapons, child protection and education, sexual violence and gender discrimination, and health care; see Geneva Call, "How We Work", available at: www.genevacall.org/how-we-work/. See also Pascal Bongard and Ezequiel Heffes, "Engaging Armed Non-State Actors on the Prohibition of Recruiting and Using Children in Hostilities: Some Reflections from Geneva Call's Experience", International Review of the Red Cross, Vol. 101, No. 911, 2019.

44 Permanent Court of International Justice, Germany v Poland, "The Factory at Chorzow", File E.c.XIII, Docket XIV:I, Judgment No. 13 (Claim for Indemnity, Merits), 13 September 1928, para. 125. The 2005 UN Basic Principles, Principles 19-23, outline the five forms of restitution, compensation, rehabilitation, satisfaction, and guarantees of non-repetition. This is developed from practice of States and jurisprudence of human rights courts, reflecting their obligations to ensure and respect human rights.

45 L. Í. Álvarez, above note 12, pp. 194-195.

46 Ibid., p. 161.

47 Interview with Túpac Amaru Revolutionary Movement (Movimiento Revolucionario Túpac Amaru, MRTA) commander, Lima, May 2019.

48 Meeting with Ogaden National Liberation Front (ONLF) commanders, Belfast, November 2018. 
recrimination, the FARC-EP commander paid the farmer for his loss. ${ }^{49} \mathrm{~A}$ hierarchy of reparation obligations could reflect that damage or loss to a person's property would be considered lower down in terms of priority than personal injury or death of civilians, and that it is still morally important to make amends for the damage caused to civilians even if it was permissible under IHL.

This article does not intend to present some rosy-eyed perspective of NSAGs as moral paragons, nor to convey that their positions are static. Not all armed groups may be willing or able to engage with civilians on reparations, and some may use intimidation and violence to discourage them from pursuing the issue. As one FARC-EP commander said, NSAGs are not "guardian angels" of civilians. ${ }^{50}$ This contrasts with Guevara's sentiment that a guerrilla army should be a "guardian angel" to the civilian population. ${ }^{51}$ There remain a number of challenges in claiming reparations, such as the identity of the responsible organization being unknown, ${ }^{52}$ the fluidity and insecurity caused by the conflict leading to a breakdown in the social and legal order in areas under the armed group's control, ${ }^{53}$ the fact that NSAGs often do not have the assets or capacity to provide reparations to all victims, ${ }^{54}$ or the political or military climate inhibiting victims or NSAGs from engaging on these issues. ${ }^{55}$

Perhaps the language of "claiming" is quite strong here, in that reparations in the circumstances described below are more a mediated solution rather than a formal legal entitlement. This does not strip them of being considered "reparations", as they still acknowledge victimhood and responsibility along with providing symbolic and material measures to alleviate victims' suffering. From analyzing the practice of different NSAGs, a general point can be made regarding their engagement on reparations to remedy a range of violations committed against civilians or their own members, on behalf of their communities, or to other groups. Five modalities can be identified that cut across the themes discussed below: (1) measures to civilians who are injured or killed by the group; (2) claims-making on behalf of the victimized communities they represent; ${ }^{56}$ (3) support for family members of comrades injured or killed in combat; (4) actions to respond to violations committed within the group; and (5) reparations for transgressions committed against other armed

49 Interview with FARC-EP commander, Bogotá, March 2019.

50 Interview with female FARC-EP commander, above note 36.

51 Ernesto Che Guevara, Guerrilla Warfare, Ocean Press, Melbourne, 2006, p. 50.

52 C. Rose, above note 4, pp. 309-310.

53 Human Rights Council, Report of the Independent International Commission of Inquiry on the Syrian Arab Republic, UN Doc. A/HRC/40/70, 31 January 2019, para. 63.

54 L. Zegveld, above note 15, p. 149.

55 R. Dudai, above note 7, pp. 785-786.

56 See "Solomon Islands Rebels "Will Not Disarm", BBC News, 14 June 2000; Denis Dumo, "South Sudan Rebels Free Kenyan Pilots after Compensation Paid, Rebel Spokesman Says”, Reuters, 19 February 2019. On the Niger Delta Avengers' demands for oil-polluted areas of the Niger Delta to be restored and affected communities to receive compensation, see Clayton D. Allen, "Pirates in West Africa and Somalia", in Caroline Varin and Dauda Abubakar (eds), Violent Non-State Actors in Africa, Springer, Cham, 2017, p. 305. 
groups. ${ }^{57}$ As such, NSAGs can use reparations as part of efforts to resolve a complex web of relations and violations, for multiple motivations. ${ }^{58}$ These practices can be best seen in how such measures are used during and post-conflict.

\section{During conflict}

NSAGs' behaviour towards civilians can be informed by ideology, contextual circumstances, access to resources and/or historical grievances. ${ }^{59}$ In protracted conflicts that can last decades, waiting for reparations until the end of hostilities may mean that victims have to live with the increasing burden of the conflict over time, such as not knowing the fate or location of the remains of a loved one. Reparations during wartime can help to mitigate further suffering and vulnerability of victims. Moreover, engagement with NSAGs on reparations for violations is pursued not only for material or symbolic gains, but also to change the behaviour of the group so that such acts do not reoccur. In Nepal, the Maoists modified or withdrew policies, carried out investigations and offered public apologies following complaints by civilians. ${ }^{60} \mathrm{~A}$ number of other groups expelled members who had committed violations, such as Dhe Qar, the Irish Republican Army (IRA) and the Taliban. ${ }^{61}$ The act of making amends by NSAGs is a means of recognizing their causal responsibility for the harm suffered by victims, not necessarily their legal or moral responsibility. ${ }^{62}$ It is notable that these public pronouncements on moral responsibility are often made with a particular intent or political goal. For the Túpac Amaru Revolutionary Movement (Movimiento Revolucionario Túpac Amaru, MRTA) in Peru, the intention was to "explain mistakes" to affected communities so as to minimize hostility. ${ }^{63}$

57 For example, after the Dinka/Nuer split in the Sudanese People's Liberation Army in the 1990s, the 1999 Wunlit Reconciliation Process provided land restitution, return of abductees and guarantees of nonrepetition. Similarly, the FARC-EP and ELN signed a pact in 2010 that acknowledged the harm done to each other and to communities, offered apologies and allegedly provided compensation to some civilians. See "Un singular pacto de paz Eln-Farc", Verdad Abierta, 28 September 2011, available at: https://verdadabierta.com/un-singular-pacto-de-paz-eln-farc/.

58 Luke Moffett, “Reparations for 'Guilty Victims': Navigating Complex Identities of Victim-Perpetrators in Reparation Mechanisms”, International Journal of Transitional Justice, Vol. 10, No. 1, 2016, p. 159.

59 See Jeremy M. Weinstein, Inside Rebellion: The Politics of Insurgent Violence, Cambridge University Press, 2007; International Committee of the Red Cross (ICRC), The Roots of Restraint in War, Geneva, 2018, p. 22; Juan Ugarriza and Matthew Craig, "The Relevance of Ideology to Contemporary Armed Conflicts: A Quantitative Analysis of Former Combatants in Colombia", Journal of Conflict Resolution, Vol. 57, No. 3, 2012, p. 447.

60 Mahendra Lawoti, "Evolution and Growth of the Maoist Insurgency in Nepal", in Mahendra Lawoti and Anup Kumar Pahari (eds), The Maoist Insurgency in Nepal: Revolution in the Twenty-First Century, Routledge, Hoboken, NJ, 2009, p. 17.

61 Vera Mironova, From Freedom Fighters to Jihadists: Human Resources of Non-State Armed Groups, Oxford University Press, Oxford, 2019, p. 86; "IRA Expels Three after Killing", BBC News, 26 February 2005; Yoshinobu Nagamine, The Legitimization Strategy of the Taliban's Code of Conduct: Through the One-Way Mirror, Palgrave Macmillan, Basingstoke, 2015, p. 98.

62 Scott Paul, "The Duty to Make Amends to Victims of Armed Conflict", Tulane Journal of International and Comparative Law, Vol. 22, No. 1, 2013, p. 101.

63 Interview with MRTA commander, above note 47. This reflects Guevara's guidance that guerrillas should explain decisions to the civilian population in order to maintain their legitimacy. 
The next part of this section outlines the benefits of "buy-in" for NSAGs engaging in reparative practices, including for ideological, governance and social ties, as well as image restoration justifications. The subsequent part discusses some of the challenges, risks and costs of making reparations during armed conflict for NSAGs and civilians.

\section{Buy-in}

The practice of reparation by NSAGs during conflict builds on recent studies on the internalization of norms evidenced by fighters' restraint in the use of violence. This reflects the asymmetrical nature of internal armed conflicts, whereby NSAGs are out-gunned and often out-resourced by the State, leaving them dependent on local communities for support and survival; this restrains their violence, but these communities also expect some moral consistency in behaviour towards them, including making reparations when violations occur. ${ }^{64}$ This conduct manifests in the ideology, governance and expressivism or imagery of armed groups. These three areas reflect the different facets in the ways that armed groups conceive and present themselves to each other, themselves and the world in terms of reparations.

\section{Ideological}

A number of codes of conduct by armed groups include provisions for remedies, reflecting these groups' ideological approach to the conduct of hostilities. Maoistinfluenced groups in particular make reference to restitution or repair. This is unsurprising given Mao's metaphor of the relationship between guerrillas and the people being like fish in the water. Mao stipulated that a group should "return everything borrowed" and "compensate all damages". ${ }^{65}$ The Viet Cong Code of Discipline makes reference to "restitution for things damaged" ${ }^{66}$ Even the Sierra Leonean Revolutionary United Front instructs members in its code of conduct "to pay for everything that you demand or damage", despite being notorious for its violations against civilians. ${ }^{67}$ Other groups include specific provisions for reparations, with the Colombian National Liberation Army (Ejército de Liberación Nacional, ELN) requiring members "to make reparations where possible" when damage is caused to civilians. ${ }^{68}$

Internal codes of conduct can be a rules-based approach to improving respect for civilians by armed groups and maintaining their confidence and trust,

64 Nelson Kasfir, "Rebel Governance-Constructing a Field of Inquiry: Definitions, Scope, Patterns, Order, Causes", in Ana Arjona, Nelson Kasfir and Zachariah Mampilly (eds), Rebel Governance in Civil War, Cambridge University Press, Cambridge, 2015, p. 39; Stathis N. Kalyvas, The Logic of Violence in Civil War, Cambridge University Press, Cambridge, 2006, p. 14.

65 Three Main Rules of Discipline and Eight Points for Attention of Comrade Mao Zedong.

66 Viet Cong Code of Discipline, Rule 4.

67 Revolutionary United Front, Eight Codes of Conduct. See Olivier Bangerter, Internal Control: Codes of Conduct within Insurgent Armed Groups, Small Arms Survey Occasional Paper No. 31, 2012, p. 70.

68 ELN Code of War, 1995. 
such as with the Taliban and its Layeha. ${ }^{69}$ In some IRA apologies, the group referred to its own code of conduct as a normative and self-legitimizing function in offering symbolic reparations to victims, but at the same time narrowly framed its wrongdoing, such as expressing remorse for the secret burial of informers rather than for their killings. ${ }^{70}$ The issuing of new written codes of conduct after violations could also be considered a guarantee of non-repetition, provided that they are complied with. ${ }^{71}$ For instance, the Taliban code of conduct stipulates that those who have violated their rules can have their weapons removed, be punished or be barred from the group. ${ }^{72}$

The practice of reparations by NSAGs during conflict is often conducted more discretely, in private with victims, their families or their communities, but it can be influenced by local culture or emotions. ${ }^{73}$ It can also be apparent in the courts of armed groups, which can offer reparative measures such as compensation. One example is the Karen National Union, where there is a preference for mediation and settlement, with failure to achieve this being seen as shameful. ${ }^{74}$ The relationship between civilians and an NSAG is not only simply one of anarchy, nor is it based simply on ideology, though it can shape the "particular form of social order". ${ }^{75}$ Reparations can be necessary as a governance issue in maintaining relations with civilians, which may organically develop or be a bargain struck between the civilians and the NSAG.

\section{Governance and social ties}

Some armed groups can be predatory or criminal in nature and have no concern for maintaining civilian relations or carrying out governance services. Nevertheless, civilian collaboration can be highly valued by armed groups for their sustainability and survivability, ${ }^{76}$ in particular to avoid informers and civilian support of competitors. Although governance by NSAGs often focuses on the provision of public services, ${ }^{77}$ this subsection of the article takes a broader approach by also looking at the social connections between civilians and NSAGs

69 Hyeran Jo and John Niehaus, "Through Rebel Eyes: Rebel Groups, Human Rights, and Humanitarian Law”, Law and Contemporary Problems, Vol. 81, No. 4, 2018, p. 114.

70 R. Dudai, above note 7, p806-807.

71 For example, Libyan National Transitional Council, "The Treatment of Detainees and Prisoners", Benghazi, 25 March 2011. See also K. Mastorodimos, above note 40, p. 128.

72 See Islamic Emirate of Afghanistan, "Layeha: A Jihadi Code of Conduct", 2006, section 10, para. 47.

73 See Kieran McEvoy, Cheryl Lawther and Luke Moffett, "Changing the Script: Non-State Armed Groups, Restorative Justice and Reparations", Journal of Human Rights Practice, 2021 (forthcoming).

74 Annika Pohl Harrisson and Helene Maria Kyed, "Ceasefire State-Making and Justice Provision by Ethnic Armed Groups in Southeast Myanmar", Journal of Social Issues in Southeast Asia, Vol. 34, No. 2, 2019, pp. 306-308.

75 Ana Arjona, Rebelocracy: Social Order in the Colombian Civil War, Cambridge University Press, New York, 2016, p. 301.

76 J. M. Weinstein, above note 59, p. 18.

77 Zachariah Mampilly, Rebel Rulers: Insurgent Governance and Civilian Life during War, Cornell University Press, Ithaca, NY, 2011, p. 4. 
in managing territory under the latter's control. Political mobilization of membership for NSAGs can often draw upon pre-existing social-cultural ties and values in order to find solidarity with civilians. ${ }^{78}$ This may involve cooperating with or co-opting local or cultural governance or mediation institutions, which can depend on the quality of organization of pre-existing institutions and willingness to engage with the armed group -i.e., mutual trust. ${ }^{79}$ Ultimately it is about coexistence, with one not overtly interfering in the life of the other. ${ }^{80}$ As Arjona, Kasfir and Mampilly put it,

rebels cannot fight wars effectively while holding a gun to the head of every civilian, nor have the financial rewards alone proven sufficient for ensuring civilian compliance. ... By creating systems of governance, rebels seek to win over local populations - or at least dissuade them from actively collaborating with incumbents. ${ }^{81}$

Social ties between armed groups and civilians reflect broader trends and dynamics of violence in armed conflicts, whereby violence against civilians and restraint are strategic choices of armed groups that speak to their domestic and international audiences. ${ }^{82}$ Restraint consists of "deliberate actions to limit the use of violence". ${ }^{83}$ There are audience costs to using violence against civilians, including reduced financial, recruitment, and moral and logistical support from sympathetic local communities and external donors. ${ }^{84}$ Some armed groups have access to resource-rich environments or committed external supporters that enable them to use indiscriminate violence, ${ }^{85}$ but many armed groups do not have a consistent supply of resources, making them more reliant on social capital and the moral restraint of supporters. This reflects the "symbiotic" character of the relationship between NSAGs and civilian populations, which can create strategic opportunities but also humanitarian risk and insufficient resources to sustain guerrilla groups. ${ }^{86}$

78 Abdulkader H. Sinno, "Armed Groups' Organizational Structure and Their Strategic Options", International Review of the Red Cross, Vol. 93, No. 882, 2011, p. 313.

79 A. Arjona, above note 75, pp. 73, 212; Shane Joshua Barter, "The Rebel State in Society: Governance and Accommodation in Aceh, Indonesia", in A. Arjona, N. Kasfir and Z. Mampilly (eds), above note 64, p. 234; Till Förster, "Dialogue Direct: Rebel Governance and Civil Order in Northern Côte d'Ivoire", in A. Arjona, N. Kasfir and Z. Mampilly (eds), above note 64, p. 206.

80 A. Arjona, above note 75, p. 2.

81 Ana Arjona, Nelson Kasfir and Zacariah Mampilly, "Introduction", in A. Arjona, N. Kasfir and Z. Mampilly (eds), above note 64, p. 3.

82 Jessica Stanton, Violence and Restraint in Civil War: Civilian Targeting in the Shadow of International Law, Cambridge University Press, Cambridge, 2016, p. 7; Sukanya Podder, "Understanding the Legitimacy of Armed Groups: A Relational Perspective", Small Wars \& Insurgencies, Vol. 28, No. 4-5, 2017, p. 686.

83 ICRC, above note 59, p. 18.

84 Max Abrahms, Rules for Rebels: The Science of Victory in Militant History, Oxford University Press, Oxford, 2018, pp. 74-78.

85 J. M. Weinstein, above note 59, p. 7; ICRC, above note 59, p. 22.

86 J. M. Weinstein, above note 59, p. 173; Achim Wennmann, "Economic Dimensions of Armed Groups: Profiling the Financing, Costs, and Agendas and Their Implications for Mediated Engagements", International Review of the Red Cross, Vol. 93, No. 882, 2011, p. 336. 
Ensuring effective restraint requires a certain level of organizational structure to control the use of opportunistic violence; ${ }^{87}$ increasing and consolidating power over the rank and file is key to restraining violence against civilians, but cannot always prevent it. The International Committee of the Red Cross (ICRC) Roots of Restraint in War study distinguishes between centralized, decentralized and community-based organizations, with important implications for behaviour. ${ }^{88}$ Centralized NSAGs can improve discipline and restrain violence through their command structure, codes of conduct, education, sanctions, and vetting out those likely to use unrestrained violence. ${ }^{89}$ Decentralized and community-based organizations, which are unlikely to have a written code of conduct or formalized sanctions regime, are more likely to rely on shared values, traditions and local leaders to manage the use of violence. ${ }^{90}$ That said, violence by community-based organizations can be seen as acceptable "swift justice" by communities - for example, vigilante punishment attacks for individuals involved in anti-social behaviour, such as burglary and drug dealing, or revenge against other communities or actors that have victimized the community. ${ }^{91}$ Moreover, socialization and integration of norms can differ within an organization, which may have competing sources of authority to shape such norms. ${ }^{92}$

The organizational structure of a group can reinforce the hierarchy of reparation obligations that NSAGs have the capacity to coherently provide. Centralized organizations that control territory are more able to set down strong community bonds with local civilians and provide reciprocal services, ${ }^{93}$ reflecting their capacity to provide more substantive redress such as health care. Community-based organizations may be able to draw upon their embedded position in a local populace, but they will likely have limited resources and mobile membership, and be restricted to local practices that may vary between different units. Accordingly, such groups may only be able to offer token compensation, "bonds of hope" 94 or symbolic measures such as a public acknowledgement of responsibility or an apology in the media or in private to the victim or their family.

The variance of the organization and relationship of NSAGs with civilians can mean they have a range of social interactions and governance arrangements. This can vary from decentralized armed groups intimidating civil society organizations to more centralized or community-based groups shaping and

87 J. Stanton, above note 82, p. 15.

88 ICRC, above note 59, p. 21. See also A. H. Sinno, above note 78, who examines patronage-based groups that are common in Yemen and Afghanistan, as well as US use of contractors.

89 M. Abrahms, above note 84 , p. 9.

90 ICRC, above note 59, p. 23; A. H. Sinno, above note 78, p. 313.

91 Olivier Bangerter, "Reasons Why Armed Groups Choose to Respect International Humanitarian Law or Not", International Review of the Red Cross, Vol. 93, No. 882, 2011, p. 380.

92 ICRC, above note 59, p. 65.

93 A. H. Sinno, above note 78 , p. 319.

94 E. C. Guevara, above note 51, pp. 50, 104. Guevara used the phrase "bonds of hope" to refer to a common interest in socially reforming society that would benefit the masses, but also, in particular, to a promissory note to recompense peasants or merchants from whom the guerrillas had taken goods or services, which was to be paid as a soon as possible. 
leading the articulation of civil society political demands for formal or informal governance processes. ${ }^{95}$ Often such armed group governance arises from the absence of the State, meaning that communities' access to justice and reparations is limited; this may be due to physical access, such as crossing a front line, or the risk of being identified as an informer through engaging with State institutions.

While it may be speedier and cheaper than that provided by State institutions, the provision of justice by NSAGs often does not incorporate procedural protections for participants. ${ }^{96}$ This may create challenges in victims being able to effectively articulate their needs in terms of reparations and seeking effective redress. Creating or supporting judicial institutions can help an armed group to consolidate power by offering a way to extend the group's social control and in turn gain legitimacy with civilians, by effectively engaging in State governance mimicry. ${ }^{97}$ This approach allows the group to "penetrate a community, obtain information about its members and their networks, gain legitimacy, and control civilian behaviour". ${ }^{98}$ The FARC-EP's provision of courts and ordering measures such as compensation or repairing schools and roads by offenders were considered a way to meet governance expectations and to maintain the group's legitimacy in the community. ${ }^{99}$

Civilians are not just vulnerable, passive individuals during conflict, but have agency to shape and pressure NSAG activities. ${ }^{100}$ Increasing social interaction and "value reciprocity" between NSAGs and civilians can provide non-fighters with a basis for claims-making to the armed group. ${ }^{101}$ Civilian engagement with armed groups can include protests, threats, and dialogue aimed at shaping outcomes to civilians' ends, such as seeking the return of stolen property. Such engagement can provide civilians with a way to cope and manage or mediate conflict with arms carriers.

These structural and social factors can have implications for the delivery of reparations by NSAGs, both in terms of the capacity and values of the group. NSAGs' governance and their provision of reparations can be a means for them to extend their legitimacy as "symbolic expressions of power". ${ }^{102}$ NSAGs may make apologies or carry out other forms of symbolic reparations, such as creation of memorials or acknowledgments of responsibility, as a way to restore their image to local and international audiences. ${ }^{103}$ However, such efforts may be framed to limit the NSAG's own responsibility, in particular their intent, putting

95 Enrique Desmond Arias, Criminal Enterprises and Governance in Latin America and the Caribbean, Cambridge University Press, Cambridge and New York, 2017, p. 139.

96 Ibid., p. 61. Respondent members of NSAGs spoke about carrying out punishment shootings, beatings, killings, public restraints (tying to a lamppost or a tree) and exile of perpetrators.

97 A. Arjona, above note 75, p. 72.

98 Ibid., p. 73.

99 René Provost, "FARC Justice: Rebel Rule of Law”, UC Irvine Law Review, Vol. 8, No. 1, 2018, p. 251.

100 See Oliver Kaplan, Resisting War: How Communities Protect Themselves, Cambridge University Press, Cambridge and New York, 2016.

101 S. Podder, above note 82, p. 691.

102 Zachariah Mampilly, "Performing the Nation-State: Rebel Governance and Symbolic Processes", in A. Arjona, N. Kasfir and Z. Mampilly (eds), above note 64, p. 74.

103 M. Abrahms, above note 84, p. 182. 
out the message that loss of life was collateral damage or beyond the group's control. ${ }^{104}$ Governance can impose a substantial burden on armed groups that can discourage many from carrying out such activities or engaging in more shared governance arrangements. ${ }^{105}$ NSAG governance has to be flexible and at times highly mobile, meaning that it can be temporary if it is defeated or displaced permanently from a territory. ${ }^{106}$ That said, in the absence or distrust of the State, NSAGs may provide an avenue for victims to seek redress.

Providing reparations can also benefit the armed group in other ways. Ensuring reparations are made for wrongs committed against civilians can be a way of improving morale and discipline. ${ }^{107}$ In addition, it is an internally and externally facing accountability process that enables the group's code of conduct and humanitarian norms to be reiterated and complied with. Making reparations to civilians may allow the group to take the moral high ground and vindicate its members' own self-image as honourable fighters in contrast to the State's violations or other NSAGs. However, there remain risks and limitations, with reparations potentially appearing as inadequate, insincere or propaganda. This can be seen in how armed groups engage in measures such as reparations to restore their own image.

\section{Image restoration}

There is some research which suggests that violence by armed groups is expressive, in that their actions, whether violent or not, are a way to promote moral and political messages that they seek to cultivate in contrast to those of the State or other actors. This is apparent in armed groups claiming responsibility for an attack as a way to publicize their abilities, convey a political message (including how those affected deserved such violence), and/or demonstrate the weakness, corruption or inability of the State to prevent such violence. ${ }^{108}$ Yet using violence as a communicative tool is a "flawed" strategy; while it can grab media headlines, States, civil society and victims can misinterpret the motives and agenda of the group. ${ }^{109}$ NSAGs may not always be forthcoming where their operation or attack resulted in civilian loss that received local, national and/or international condemnation. Claiming responsibility or apologizing for an act is a way to mitigate public condemnation, in particular where there are high civilian casualties for little military gain. ${ }^{110}$ Abrahms points out that groups often turn to denying their

104 See, for instance, Al-Qaeda's apology for attacking a hospital, and the so-called Islamic State's apology for attacking the Israeli Defence Force. Yousuf Basil and Catherine E. Shoichet, "Al Qaeda: We're Sorry about Yemen Hospital Attack", CNN, 22 December 2013; Judah Ari Gross, "Ex-Defense Minister Says IS 'Apologized' to Israel for November Clash", Times of Israel, 24 April 2017.

105 J. M. Weinstein, above note 59, p. 171.

106 S. J. Barter, above note 79, p. 228; A. Wennmann, above note 86, p. 336.

107 O. Bangerter, above note 91, pp. 361-362.

108 S. N. Kalyvas, above note 64, p. 26.

109 M. Abrahms, above note 84, pp. 55-56.

110 Ioana Emy Matesan and Ronit Berger, "Blunders and Blame: How Armed Non-State Actors React to Their Mistakes”, Studies in Conflict \& Terrorism, Vol. 40, No. 5, 2017, p. 381. 
involvement as a way to distance themselves from some wayward members of the group and to minimize the cost in terms of audience support for the group. ${ }^{111}$ Nevertheless, the claiming of responsibility and partial or full censure of the actions of the group's members evinces a form of accountability in that the armed group is intending to communicate norms and values. ${ }^{12}$

NSAGs presenting themselves as complying with IHL can potentially widen mobilization. ${ }^{113}$ Engaging in the human rights discourse or incorporating humanitarian norms to remedy harm to victims, or at least provide them with assistance, can give the group a competitive advantage over other groups, as a unique selling point to domestic and international audiences. ${ }^{114}$ Other groups may carry out reparative practices not as part of organized governance but as a way to maintain their respect for cultural norms. For instance, the Ethiopia-based Ogaden National Liberation Front (ONLF) compensates the families of civilians accidentally killed by the group as something "for our own benefit as people need to support the war effort". ${ }^{115}$ There are also reports of the ONLF killing enemy collaborators and leaving the "necessary blood compensation in cash with the corpse in order to prevent revenge from the victim's kin". ${ }^{116}$

Armed groups can also be representations of their political community; this is not to say that all armed groups are social activists, but they often have close political, social and practical links with civilians that precipitate and perpetuate their ability to fight. Violence is seen as a way of "speaking for" or "defending a community", and of taking action rather than expecting handouts. ${ }^{117}$ These perceptions and representations of the group can be embedded in notions of sacrifice, honour and loyalty, which can serve to motivate and justify the continuing use of violence. ${ }^{18}$ When violations do occur, reparations by armed groups can signal their "goodwill" and cast them in a more positive light. ${ }^{119}$ However, civilians or victims may reject such expressions and gestures of reparations as self-serving or insincere, such as the apology of the New IRA for the killing of the journalist Lyra McKee in Derry in 2019. ${ }^{120}$ Civilians can also resist or reject reparations by NSAGs in order to deny any social connection to them or to avoid recrimination; one example of this is the woman whose family

111 M. Abrahms, above note 84, p. 174.

112 K. Fortin, above note 10, p. 171.

113 S. Podder, above note 82, p. 691.

114 A. Clapham, above note 19,.p. 33.

115 Meeting with ONLF commanders, above note 49.

116 Tobias Hagmann, "Beyond Clannishness and Colonialism: Understanding Political Disorder in Ethiopia's Somali Region, 1991-2004”, Journal of Modern African Studies, Vol. 43, No. 4, 2005, p. 533, fn. 34.

117 Bill Rolston, "Demobilization and Reintegration of Ex-Combatants: The Irish Case in International Perspective", Social and Legal Studies, Vol. 16, No. 2, 2007, p. 262.

118 See Cheryl Lawther, "The Truth about Loyalty: Emotions, Ex-Combatants and Transitioning from the Past", International Journal of Transitional Justice, Vol. 11, No. 3, 2017.

119 M. Abrahms, above note 84, pp. 182-183.

120 The apology read: "In the course of attacking the enemy Lyra McKee was tragically killed while standing beside enemy forces. The IRA offer our full and sincere apologies to the partner, family and friends of Lyra McKee for her death. ... We have instructed our volunteers to take the utmost care in future when engaging the enemy, and put in place measures to help ensure this." See Connla Young, "New IRA Admits Murder of Journalist Lyra McKee and Offers 'Sincere Apologies", Irish News, 23 April 2019. 
bicycle was taken by the FARC-EP, which later returned with a new one, but the woman refused it for fear of the army finding out. ${ }^{121}$ NSAGs selling or repackaging the violence of the armed struggle as legitimate, justified or remediable when excesses occur, and using reparations to support this view, raises other challenges.

\section{Challenges, risks and costs}

The instrumental use of reparations by NSAGs raises three challenges in terms of legitimization of violence, security risk and financial cost. First, encouraging NSAGs to engage in reparations may be a means to further embed their legitimacy and perpetuate the conflict. This may, in turn, inhibit the NSAG from engaging in reparations to victims on the other side. Hezbollah provided compensation to those affected by Israeli strikes, but not to Israeli victims injured or killed in its attacks. ${ }^{122}$ This may be something that requires distance and space from the day-to-day activities of the armed conflict, to see the other side not as the enemy, but as human beings. ${ }^{123}$ One former Colombian M-19 commander disclosed that after the end of hostilities and her work in peacebuilding, she came into contact with a police officer who said, "I was a policewoman and you can tell me that I was a victimizer, but then I was also a victim of the FARC." This led the M-19 commander to recognize that the binary of victim-victimizer is "polarizing" and a "vicious circle". 124

In some conflicts shifting alliances can mean that victimhood is used to manipulate ethnic, political or national identities in the pursuit of legitimacy and State power, meaning that "all civilians are fair game". ${ }^{125}$ Indeed, collective victimhood can be used by all sides to build a communal identity and portray themselves as innocent and deserving of sympathy. ${ }^{126}$ In light of this collective victimhood and acting on behalf of aggrieved communities, civilians can also join armed groups as a way to "redress grievances". ${ }^{127}$ Armed groups can be motivated to communicate their grievances to those responsible, but often "their grievances exceed their capability to redress them". ${ }^{128}$ This was expressed by exfighters we interviewed whose friends and family members had been killed. This

121 O. Kaplan, above note 100, p. 251.

122 Sarah Holewinski, "Making Amends: A New Expectation for Civilian Losses in Armed Conflict", in Daniel Rothbart, K. V. Korostelina and Mohammed D. Cherkaoui (eds), Civilians and Modern War, Routledge, London and New York, 2012, p. 328.

123 Danny Morrison, a former IRA prisoner, wrote in his prison diary that he wished to see a police officer kidnapped by the IRA in South Armagh released, as " $[\mathrm{t}]$ here can never be enough demonstrations of mercy in war". Danny Morrison, Then the Walls Came Down: A Prison Journal, Mercier Press, Cork, 2018, pp. 96-97. Thanks to Kevin Hearty for this reference.

124 Interview with female former M-19 commander, Bogotá, March 2019.

125 Wendy Isaacs-Martin, "The Séléka and Anti-Balaka Rebel Movements in the Central African Republic", in C. Varin and D. Abubakar (eds), above note 56, p. 150.

126 Daniel Bar-Tal, Lily Chernyak-Hai, Noas Schori and Ayelet Gundar, "A Sense of Self-Perceived Collective Victimhood in Intractable Conflicts", International Review of the Red Cross, Vol. 91, No. 874, 2009.

127 A. Arjona, above note 75, p. 265; ICRC, above note 59, p. 14.

128 M. Abrahms, above note 84, p. 1. 
is not to justify the violence of such groups, but reflects that the lack of effective State enforcement and remedial mechanisms to allow the law to settle disputes allowed grievances to fester.

An armed group may have limited resources to allocate to reparations, offering compensation that is only a token amount or is insufficient to remedy a victim's suffering. The Taliban's 2016 policy of making amends was small-scale and more symbolic than real due to the financial cost, making its use mainly strategic in terms of maintaining political appearances or public relations. ${ }^{129}$ Violence can also be a means of social control, but greed and grievance can still play a part in the activities of NSAGs that may inhibit their motivation to engage in reparations. The passage of time and the impact of the conflict on the economy and local resources can mean increasing poverty, stressing the group's governance structures or causing its members' ideological adherence to become weaker. ${ }^{130}$ Armed groups may no longer have access to the same financial resources to provide compensation or other measures to victims, making such reparations a costly war strategy. This reflects the hierarchy of reparations challenges when dealing with NSAGs with differing capacities, whereby the most some victims will receive may be an apology rather than compensation. ${ }^{131}$

There are risks for those involved, including being targeted for further violence, unequal power dynamics and bargaining power, which may signal weakness to other groups, ${ }^{132}$ and fragmentation. ${ }^{133}$ Members of NSAGs may be unable or lack the capacity to adjudicate on violations, and such adjudications would be unlikely to meet basic principles of fair process such as independence, promptness and evidential integrity. Of course, armed groups have volunteers and supporters who come from a range of backgrounds, and can provide independence by engaging local community leaders to act as arbitrators. ${ }^{134} \mathrm{~A}$ further difficulty is that if NSAGs make reparations during conflict, such measures may not be recognized as legitimate by the State or other actors, such as the restitution of land, death certificates for missing persons, or registration of births of those abducted. Alternatively, reparations by NSAGs may be used by prosecutors to evidence recognition of wrongdoing by the group or individual members of a NSAG in war crimes trials, which may discourage their efforts to repair. ${ }^{135}$ If victims are not satisfied with the remedy offered by the armed group, they are unlikely to be able to appeal to a State court or have the initial decision

129 Ashley Jackson and Rahmatullah Amiri, Insurgent Bureaucracy: How the Taliban Makes Policy, United States Institute of Peace, Washington, DC, 2019, p. 36.

130 S. N. Kalyvas, above note 64, p. 115.

131 This does not displace their right to reparations from State reparation programmes.

132 Cyanne E. Loyle and Helga Malmin Binningsbø, "Justice during Armed Conflict: A New Dataset on Government and Rebel Strategies", Journal of Conflict Resolution, Vol. 62, No. 2, 2016, p. 460.

133 See Hichem Khadhraoui, "Fragmentation of Armed Non-State Actors in Protracted Armed Conflicts: Some Practical Experiences on How to Ensure Compliance with Humanitarian Norms", International Review of the Red Cross, Vol. 101, No. 912, 2019.

134 In Aceh, see S. J. Barter, above note 79, p. 234.

135 The International Criminal Court allows mitigation in sentencing for those who compensate their victims (Rules of Procedure and Evidence, Rule 145(2)(a)(ii)) or who help to locate assets for the benefit of victims (Rome Statute, Art. 110(4)). 
recognized as legal. In post-conflict societies, reparation programmes may be better placed to accept evidence from victims or NSAG courts as supporting evidence for claims, provided they could be corroborated. At the same time, NSAGs actively mediating with civilian constituencies during conflict and providing reparations can contribute to a more peaceful future as they can be considered as more acceptable for social reintegration; an example of this is the greater willingness by the Peruvian MRTA to engage in auto-criticism to communities and before the Peruvian truth commission in comparison to the more violent and unrepentant Shining Path. ${ }^{136}$

\section{Post-conflict}

Peace agreement negotiations or transitional justice processes may provide an opportunity for the violations of all sides to be remedied. NSAGs can play an important part in reparation processes, whether as victims, responsible actors, facilitators or advocates. For instance, the Ugandan Lord's Resistance Army wanted "compensation for losses" for itself as part of the Juba peace negotiations. ${ }^{137}$ Armed groups can also advocate for more comprehensive reparations for victims, such as the Zapatistas demanding more than compensation for the damage caused to indigenous lands. ${ }^{138}$ In peace agreements, armed groups have committed to giving compensation to victims, ${ }^{139}$ assisting in the recovery of disappeared persons, ${ }^{140}$ establishing trust funds for victims' rehabilitation, ${ }^{141}$ restitution of land and property, ${ }^{142}$ repatriation of displaced persons, ${ }^{143}$ measures of satisfaction to publicly acknowledge harms caused, and guarantees of non-repetition of violations. ${ }^{144}$ Some groups take a comprehensive approach to reparations, such as the National Democratic Front

136 The Shining Path was a more secretive organization during the conflict, whereas the MRTA was more media-savvy in managing its image as a social justice armed group. See Rebekka Friedman, Competing Memories: Truth and Reconciliation in Sierra Leone and Peru, Cambridge University Press, Cambridge, 2017, p. 148; and Nelson Manrique, “The War for the Central Sierra”, in Steve J. Stern (ed.), Shining and Other Paths: War and Society in Peru 1980-1995, Duke University Press, Durham, NC, 1998, p. 213, citing the example of the MRTA apologizing after killing an indigenous leader for collaborating with the State, resulting in the community rebelling against the group.

137 "Uganda Rebels Want Army Disbanded”, BBC News, 18 July 2006.

138 "Joint Declaration that the Federal Government and the EZLN Shall Submit to National Debating and Decision-Making Bodies", 16 February 1996, p. 3, para. 3(2).

139 Townsville Peace Agreement, 2000, Part 3(1)(b); Memorandum of Understanding between the Government of the Republic of Indonesia and the Free Aceh Movement, 2005, Art. 3.2.5; Agreement on Accountability and Reconciliation Signed between the Government of the Republic of Uganda and the Lord's Resistance Army/Movement, 2007, Arts 6(4), 9(3); Agreement between the Government of Sudan and the Justice and Equality Movement - Sudan on the Basis of the Doha Document for Peace in Darfur, 2013, Article 17.

140 Townsville Peace Agreement, 2000, Part 3(1)(a).

141 Accord politique pour la paix et la réconciliation en république centrafricaine, February 2019, Art. 12.

142 In Nepal, the Seven Point Agreement, 1 November 2011, para. 6(a).

143 Bogotá Accord, 1984, Art. 3(6); Liberian Comprehensive Peace Agreement, 2003, Arts XIV(4), XXX.

144 Lome Peace Agreement, 1999, Art. XXV; Nationwide Ceasefire Agreement between the Government of the Republic of the Union of Myanmar and the Ethnic Armed Organizations, 2015, Art. 25. 
of the Philippines, which committed to "adequate compensation or indemnification, restitution and rehabilitation, and effective sanctions and guarantees against repetition and impunity". ${ }^{145}$ This seems to be a recent phenomenon, heightened by the FARC-EP peace agreement, as former fighters in Colombia that we spoke to, such as those of the M-19, and former non-State fighters in Guatemala, Nepal and Northern Ireland had no specific agenda for reparations. One former Guatemalan guerrilla commander spoke about his group's eagerness to engage in reparations, but the government was unwilling to give the group a "chance to participate". ${ }^{146}$

There is also the challenge of transforming the financial structures of a group, which can be fixated on by some victims as a source of reparations. ${ }^{147}$ The responsibility of armed groups to fund reparations has implications for the resources available and expectations of the NSAG's wealth, and can have an effect on trust when such sources do not appear. This is apparent in Colombia, where despite research suggesting that the FARC-EP was making over $\$ 1$ billion annually, the group had only turned over $\$ 12.9$ million of nearly $\$ 300$ million promised for reparations by the end of $2020 .{ }^{148}$ NSAGs' financial contributions to reparation programmes that could benefit their own victimized members need to have robust financial regulation and auditing to avoid them being a vehicle for money laundering. At the same time, there need to be means to secure such resources for reparations, otherwise they can result in lengthy and complex legal proceedings. For instance, in Northern Ireland, litigation by some victims of the 1998 Omagh bombing that killed twenty-nine civilians against members of the Real IRA was successful in holding the latter liable for $£ 1.6$ million. While the victims have never received any money, their objective was to hold those responsible to account. ${ }^{149}$

This practice can reflect the dual dimensions of reparation as justice and delivering political goals of reconciliation and trust. The experience in many transitional societies shows that coercive policies to seek reparations from NSAGs have proved fruitless; however, there are some encouraging praxes where members and former armed groups are incentivized to engage on reparations. In Northern Ireland, for instance, loyalist and republican armed groups have carried out informal truth recovery for victims along with apologies and acknowledgments of responsibility. ${ }^{150}$ Yet such informal processes are at risk of abuse and of material being used in criminal proceedings, such as when Gerry Adams, leader of Sinn Fein, was arrested for information that was provided by former IRA members to an oral

145 Comprehensive Agreement on Respect for Human Rights and International Humanitarian Law between the Government of the Republic of the Philippines and the NDFP, 16 March 1998, Art. 2(3).

146 Interview with former guerrilla commander, Guatemala City, May 2018.

147 A. Wennmann, above note 86 , p. 350.

148 Nelson Bocanegra, Colombia's FARC Delivers a Fraction of Pledged Peace Deal Assets by Deadline, Reuters, 31 December 2020.

149 See L. Moffett, above note 27.

150 Interview with former UVF member, Belfast, 6 April 2018. 
history archive. ${ }^{151}$ Such experiences have left little trust or political willingness on the part of such groups to engage with victims or redress the past.

There are legal, political and social dynamics for NSAGs moving from war to peace. At the end of hostilities, the organized military structure of the armed group is dissolved through demobilization and so it can be difficult to speak about the collective responsibility of a group that the State and the group's own (former) members agree no longer exists. ${ }^{152}$ Nonetheless, the political wing of the former armed group may remain the representative voice and organizer for such engagement on reparations, in particular symbolic measures such as apologies and acknowledgments of responsibility. ${ }^{153}$ For such measures to be effective, the person providing the apology must have the necessary position, authority and legitimacy within the group to be able to speak for it. ${ }^{154}$ Here there may be tension between political leaders speaking for actions carried out by military commanders, and this tension may fracture the coherence of the group as a political community. Victims may want the direct perpetrator or a military leader to apologize rather than a spokesperson or political representative, as the latter may make the apology seem more like a political statement rather than a remedial effort by those responsible to account for and repair the harm they have caused. ${ }^{155}$

For armed groups to lay down their arms, it requires them to some extent to no longer recognize the continuation or justification of the armed struggle (or at least to recognize that the conditions or their grievances have been alleviated) and to accept the authority and legitimacy of the State. ${ }^{156}$ However, this can often be strained by bad faith on the part of the government; internal dissidence within the group or ex-fighters turning to crime, leading to continued low-level violence; ${ }^{157}$ or even the group's own mythologized, self-justified political narrative of the past. ${ }^{158}$ In Northern Ireland, Colombia, South Sudan, Nepal and Uganda, former fighters all expressed a concern that the political and legal context faced changing priorities from the respective peace agreements due to a lack of a comprehensive approach for dealing with the past and a lack of good

151 See Anna Bryson, "Victims, Violence, and Voice: Transitional Justice, Oral History, and Dealing with the Past", Hastings International and Comparative Law Review, Vol. 39, No. 2, 2016.

152 This may only be partial or may involve integration with State forces such as in the Democratic Republic of the Congo. Joanna Spear, "Disarmament and Demobilisation", in Stephen John Stedman, Donald Rothchild and Elizabeth M. Cousens (eds), Ending Civil Wars: The Implementation of Peace Agreements, Lynne Rienner, Boulder, CO, 2002.

153 For instance, see the FARC political party's recommitment to the peace agreement and engagement on victims of kidnapping. Juanita Vélez, "Cuando Uribe quiere tumbar la JEP, la Farc redobla compromisos con el Acuerdo", La Silla Vacia, 13 March 2020, available at: https://lasillavacia.com/ cuando-uribe-quiere-tumbar-jep-farc-redobla-compromisos-acuerdo-75815.

154 See UN General Assembly, Report of the Special Rapporteur on the Promotion of Truth, Justice, Reparation and Guarantees of Non-Recurrence, UN Doc. A/74/147, 12 July 2019, para. 32.

155 See Kieran McEvoy, Anna Bryson and Kevin Hearty, "Apologies, Armed Groups and Symbolic Redress", Journal of Human Rights Practice, 2021 (forthcoming).

156 Peter Taylor, Provos: The IRA and Sinn Fein, Bloomsbury, London, 1997, p. 66.

157 See Sarah Zukerman Daly, Laura Paler and Cyrus Samii, "Wartime Ties and the Social Logic of Crime", Journal of Peace Research, Vol. 57, No. 4, 2020.

158 Such as with ETA's apology to "those citizens without responsibility": L. Í. Álvarez, above note 12, p. 188. 
faith on the part of the new government. This can also have mental health implications for former fighters, which are often not addressed in the long term. These issues may impact upon former fighters contributing to reparations. Engagement in transitional justice mechanisms such as truth recovery or reparations that can individually identify and implicate them in past violations can only heighten the visibility of former fighters who want to start a new life. The reintegration of ex-fighters into civilian life can bring social challenges, as they can be rejected by their families or communities, or suffer discrimination or stigma. ${ }^{159}$ That said, there can be benefits and related costs to engaging in reparations that may nuance some of these issues, and engaging in reparations at least shows good faith of former members of armed groups to make amends for their past violations.

\section{Benefits and costs of non-State armed groups' engagement in reparations}

In the transition from war to peace, NSAGs, whether as political bodies or as associations of ex-fighters, may benefit from engaging in reparations and other transitional justice processes. Reparations by former fighters and the political wings of armed groups can be a means for them to recast their image and facilitate their social reintegration. This may be something that occurs not from external pressure but from within the membership of the group, and that does not necessarily have to be "reciprocated" by other responsible actors. ${ }^{160}$

Reparation can be a way to continue the social transformation that some groups hoped to obtain through arms; as one FARC-EP commander stated, it is another "tool to continue the struggle". ${ }^{161}$ This "ideological sense of self" can provide an important buy-in for fighters to see their own contribution as being a social good or part of their ongoing contribution to improve conditions in their country. ${ }^{162}$ One former loyalist in Belfast argued for "community reparation" to repair the "residual effects", such as poverty, for those most affected by violence, as otherwise "identity becomes a lot more important to people or foremost in their mind when they don't have anything else ... but [when] you start to chip at their identity ... it becomes a point of conflict". ${ }^{163}$ Reparations can also be a means for NSAGs to maintain their role as political and moral actors and to be socially active on their, and others', grievances, as the "fundamental point of reparation is to heal the causes that generated the conflict". ${ }^{164}$ This view was shared by a female Guatemalan ex-fighter who said: "We used to be guerrillas; now we are helping victims with the consequences of the war. ... We are still

159 See Grace Akello, "Reintegration of Amnestied LRA Ex-fighters and Survivors' Resistance Acts in Acholiland, Northern Uganda", International Journal of Transitional Justice, Vol. 13, No. 2, 2019.

160 Interview with former UVF member, above note 150.

161 Interview with female FARC-EP commander, above note 36.

162 See K. McEvoy, A. Bryson and K. Hearty, above note 156.

163 Interview with former loyalist group member, Belfast, April 2018.

164 Interview with female FARC-EP commander, above note 36. 
fighting and struggling here." 165 Armed groups can legitimize their struggle as positive social transformation, but this may overlook transformations that were already under way before the conflict started and were disrupted by the violence, such as in Mozambique and Peru. ${ }^{166}$

In Nepal, some Maoist cadres and supporters saw the loss of comrades and disappearance of family members as part of the cost of and continued efforts for social transformation. ${ }^{167}$ This "war by other means" by ex-fighters may be onesided. While initially the Maoists in Nepal pushed for the payment of compensation for those killed and disappeared as martyrs of State violence, they at times tried to buy off those they had victimized from pursing accountability for atrocities. For instance, the 2005 Madi bus bombing by the Maoists killed thirty-eight civilians and injured seventy-two others; after the war one of the Maoist leaders made a deal with the victims to provide them with health care, employment and an allowance to forgo truth and justice for the incident. ${ }^{168} \mathrm{~A}$ discourse also crept in between civilian martyrs and "real martyrs" in Nepal, ${ }_{169}$ in terms of who should be prioritized, and Maoist local leaders redirected funds to ex-fighters who were disqualified from the relief scheme. ${ }^{170}$ Victims resisted this by creating a memorial, giving evidence to the truth commission, and pursuing accountability. ${ }^{171}$ In response, the Maoists threatened to kill the survivors if their demands were unreasonable. ${ }^{172}$ This reflects the continuing contest over the past and the political statements and patronage by former armed groups, which may amount more to rhetoric aimed at instrumentalizing victims in the run-up to elections than advocacy for justice for those they victimized. ${ }^{173}$

Similar narratives and advocacy by former ex-fighters and armed groups' political wings may not be so generous to civilian victims. For instance, in South Africa some former fighters argued that as they had struggled against apartheid, they should be recognized as more deserving of support than civilian victims, who they saw as using the struggle for freedom for their own financial reward. ${ }^{174}$ While reparations programmes should be done concurrently with reintegration programmes, so that the different needs of civilians and ex-fighters are met, civilians are often neglected. This can mean that more money can be poured into

165 Interview with female former Guatemalan National Revolutionary Unity fighter, Guatemala, May 2018.

166 J. M. Weinstein, above note 59, p. 3.

167 Kristine Eck, "Recruiting Rebels: Indoctrination and Political Education in Nepal", in M. Lawoti and A. Kumar Pahari (eds), above note 60, p. 40.

168 “TRC Takes Exception to Dahal's Deal with Madi Blast Victims", Kathmandu Post, 6 December 2017.

169 Yvette Selim, "Examining Victims and Perpetrators in Post-Conflict Nepal", International Review of Victimology, Vol. 23, No. 3, 2017, p. 284.

170 Yvette Selim, "Contestation and Resistance: The Politics of and around Transitional Justice in Nepal", Conflict, Security \& Development, Vol. 18, No. 1, 2018, p. 50.

171 Lucas Font and Julia Fernández Cadenas, "Nepal's Civil War: 'We Are Tired of Promises, We Need Justice", Lacuna, 13 November 2018.

172 "Madi - Prachanda's Waterloo", Newsfront, 25 June-1 July 2007, p. 2.

173 One Maoist leader acknowledged that the bombing was a grave mistake, but did not apologize. "Guilty of Madi Bus Ambush Should Face Legal Action: Dahal", Kathmandu Post, 5 November 2017.

174 Brandon Hamber, "The Dilemmas of Reparations: In Search of a Process-Driven Approach”, in Koen De Feyter, Stephan Parmentier, Marc Bossuyt and Paul Lemmens (eds), Out of the Ashes: Reparation for Victims of Gross and Systematic Human Rights Violations, Intersentia, Cambridge, 2009, p. 144. 
former fighters' reintegration at an earlier stage, to prevent them from taking up arms, or they may have better access to services than civilians. Alternatively, if ex-fighters' needs are not being met they may "re-badge" themselves as victims and seek support through this pathway, which is permitted in Northern Ireland. ${ }^{175}$

Reparations claimed by victims may be counter to the armed group or its political wing's narrative of the conflict. For instance, the mobilization of families of those disappeared by republicans in Northern Ireland in the 1990s placed a very public pressure on Sinn Fein, which was trying to transition to peace, to provide information on the recovery of their remains. ${ }^{176}$ Memorialization and commemoration of those who were killed during the conflict also poses a serious source of contention where "dead body politics" is played out to contest and reinforce selective interpretations of the past. ${ }^{177}$ Such contestation and confrontation over the past may have a negative effect on a group in delegitimizing its violence or may cement its position as drawing a line under the past of the armed struggle and present its leaders distancing themselves from past violence as now being politically generous. Such shifts are dependent not only on former fighters but also on the State and civil society in allowing divergent narratives of the past and power structures to be legitimized in the aftermath of conflict. Yet this often sees a lack of good faith by former belligerents over time, wherein the violence of the past becomes a new source of meta-conflict to be politically contested in order to tarnish the other side and diminish common values. ${ }^{178}$ It also keeps alive notions of collective victimhood and unaddressed grievances, which may be used by subsequent generations to justify further violence. ${ }^{179}$

There can also be a capacity challenge for NSAGs and ex-fighters in how to handle and disclose information, engage with victims, and provide symbolic or material reparations. As one ex-fighter who engages with victims said, "we know how to destroy this building, it's very easy for us, but to build a small house was so hard". ${ }^{180}$ There are limits to engagement. In Ireland, while the republicans and their organizations took efforts to locate those who had disappeared, they did not identify those responsible for prosecution and not all those involved participated. ${ }^{181}$ Thus it is important to appreciate the diversity of groups, but also to provide space and capacity-building to be able to contribute to such processes. This may require a legal framework where ex-fighters can come forward to

175 Cheryl Lawther, "The Construction and Politicisation of Victimhood", in Orla Lynch and Javier Argomaniz (eds), Victims of Terrorism: A Comparative and Interdisciplinary Study, Routledge, London, 2014.

176 Sandra Peake and Orla Lynch, "Victims of Irish Republican Paramilitary Violence: The Case of 'The Disappeared", Terrorism and Political Violence, Vol. 28, No. 3, 2016, p. 469.

177 See Kevin Hearty, "Problematising Symbolic Reparation: 'Complex Political Victims', 'Dead Body Politics' and the Right to Remember”, Social and Legal Studies, Vol. 29, No. 3, 2020.

178 See Cheryl Lawther, "Let Me Tell You': Transitional Justice, Victimhood and Dealing with a Contested Past", Social and Legal Studies, 2020.

179 D. Bar-Tal et al., above note 126.

180 Interview with former Lebanese rebel commander, April 2018.

181 R. Dudai, above note 7, p. 801. 
acknowledge their responsibility and make amends with mitigated legal repercussions. The Colombian Special Jurisdiction for Peace (Jurisdicción Especial para la Paz, JEP) to some extent provides this framework, where members of the FARC-EP and the Colombian armed forces have made acknowledgements of responsibility as well as having to collectively contribute to reparations in exchange for reduced sentences. Of course, the JEP concentrates more on collective responsibility of the group and is complemented by a truth commission and reparations programme, which may not exist in other contexts. A bespoke approach should allow ex-fighters, victims and affected communities to find their own balance in exchanging full punishment for redress, rather than copying what operates in one context and applying it to another. Such a framework would need to nuance those most responsible for international crimes, to manage those who refuse to engage, and to have conditional elements for those who are incentivized to come forward, such as facing imposition of their sentence if they support or engage in further violence. There is a risk that without some conditionality around reparations made by NSAGs, reparations may be seen as a means to "buy off" or silence victims. ${ }^{182}$

For NSAGs, reparations may be a "dirty word", may be unfamiliar or may reflect the language of the State or colonizer. For some armed groups we engaged with, reparations were at times seen as "retributive", especially for one Irish republican group that had been in contact with members of Basque Fatherland and Liberty (Euskadi Ta Askatasuna, ETA), which had its assets seized for reparations. ${ }^{183}$ This is also clearly seen in the Somali region of Ethiopia, where the Ethiopian government introduced a law for families and clans of ONLF members to pay compensation to individuals who had been killed by the ONLF. ${ }^{184}$ This framing of reparations by States, where they have been used in bad faith to impose collective punishment rather than to ensure a remedy for victims, may have implications for NSAGs' future engagement with the concept.

Retributive discourses around the past can be a means to use reparations to impose a secondary punishment on members of NSAGs. For instance, one former commander of the MRTA had a $\$ 15,000$ reparation award imposed at the same time as his sentencing twenty-five years ago. During prison and since his release two years ago he has been paying it off in $\$ 30$ monthly instalments, but now with interest the amount is $\$ 300,000$, an impossible sum for him to pay off. His family has also had property seized, and anything he earns is subject to a judicial order of confiscation. This money does not go to the victims of his group, but to the State, which has already indemnified the victims under the national reparation

182 Roger Petersen and Sarah Zukerman Daly, "Revenge or Reconciliation: Theory and Method of Emotions in the Context of Colombia's Peace Process", in Morten Bergsmo and Pablo Kalmanovitz (eds), Law in Peace Negotiations, Tokrel Opsahl, 2010, p. 272.

183 Interview with former republican group member, Belfast, June 2018.

184 Office of the Parliament, Somali Regional State, decisions passed in the 5th Session of the 3rd House of Parliament held from 22 to 24 December 1998, cited in Human Rights Watch, Collective Punishment: War Crimes and Crimes against Humanity in the Ogaden Area of Ethiopia's Somali Regional State, 2007, p. 96. 
programme. Such an approach morally flattens the multifaceted identities in conflict between bad perpetrators and innocent victims, reinforcing exclusion and further victimization of complex victims-i.e., victimized perpetrators. ${ }^{185}$ Importantly, this misses the purpose of reparations as not being punitive but as finding a balance in interests to make amends for the past within a framework of common values that can help to prevent future repetitions of violence. Such practices may militate against engagement by former fighters taking ownership of their past wrongdoings.

\section{The role of ex-fighters and the organization of armed groups in reparations}

Former commanders of armed groups can provide continuity and political leadership around difficult issues relating to the past. Leaders of NSAGs can have a significant moral and political authority to speak "on behalf of" their communities, given their role in fighting for them, and can be well placed to advocate for peace and transitional justice issues. ${ }^{186}$ However, they should not be the only voices from their communities. The role of such commanders in providing apologies, acknowledgement of responsibility and engagement in truth recovery can give weight and value to the seriousness of the process and outcome. Such leadership may not be possible, however, as the armed group may cease to exist or such commanders may die or defect, causing some of the momentum and engagement on transitional justice to be lost. ${ }^{187}$ The group may be fragmented or face threats from dissidents for engaging in reparations. One commander of the Shining Path spoke about those former members who are paying reparations on a monthly basis as "traitors to the cause", 188 reflecting that not all members of armed groups are willing to support the transition or accept the peace.

Reintegration can play an important part in socially relocating ex-fighters back into civilian life, and reparations can contribute to mitigating some of the social distrust and resentment against them. Ex-fighters can play an important part in community political mobilization and rebuilding local social capacity in the aftermath of conflict, and this highlights the importance of their social reintegration. ${ }^{189}$ Disarmament, demobilization and reintegration (DDR) processes have been criticized for often providing pay-outs or economic opportunities for ex-fighters, but with little long-term or sustainable attention to their social reintegration. ${ }^{190}$ Moreover, the use of "reintegration" of ex-fighters can stand in stark contrast to how they see themselves as politically motivated actors fighting

185 See L. Moffett, above note 58.

186 Kieran McEvoy and Peter Shirlow, "Re-imagining DDR: Ex-combatants, Leadership and Moral Agency in Conflict Transformation", Theoretical Criminology, Vol. 13, No. 1, 2009, p. 48.

187 R. Dudai, above note 7, p. 786 ; interview with former republican group member, above note 183.

188 Interview with Shining Path commander, Lima, May 2019.

189 B. Rolston, above note 117, p. 266.

190 Ibid., pp. 263-265. 
for social transformation, particularly in relation to past victimization and marginalization, as well as their position as people who speak for a community and convey its values. ${ }^{191}$ Seeing ex-fighters as political and community actors can also help to engender their ownership on redress for violations by resonating with the NSAG's values and broader norms. Yet the issue of reciprocity may arise, in that members of an NSAG cannot engage in reparations without serious engagement by the State and other actors, such as with the issue of land reform advocated by the FARC-EP.

The experience of social reintegration of Colombian ex-fighters can also impact on their support of transitional justice. ${ }^{192}$ Where ex-fighters were recognized and accepted by their community they were more willing to engage in such mechanisms, but if they were relocated far from the areas of combat and remained anonymous, they were less likely to support transitional justice processes. ${ }^{193}$ Combat exposure can have a negative and enduring effect on exfighters' perceptions of and engagement in conflict resolution. ${ }^{194}$ Moreover, DDR processes do little to socialize ex-fighters into norms of civilian justice. ${ }^{195}$ Encouraging the collective organization of an armed group to make reparations may be more productive than making it the responsibility of individual convicted members. Using the social connections and human capacity of an NSAG can mobilize more resources for reparation engagement. In times of conflict when the armed group still militarily exists, it makes sense to speak of legal obligations as a collective, but at the end of hostilities it may make more sense to use less obligatory terms, or to incentivize former members of NSAGs to contribute in some way in exchange for reduced sentences or immunity, such as was used to encourage the disclosure of information from republican NSAGs regarding the recovery of the disappeared in Ireland. ${ }^{196}$ This reflects the hierarchy of reparation obligations when it comes to armed groups, and the complementary role of State reparation programmes.

\section{Conclusion}

Reparations are a process that aims to help victims and responsible actors to find a balance of competing interests in order to remedy the harm caused. Human rights law suggests that this should be "full reparation" as a maximal account. However, most reparation mechanisms try to find a more feasible point that not only

191 K. McEvoy and P. Shirlow, above note 186, p. 33.

192 Sarah Zukerman Daly, "Determinants of Ex-Combatants' Attitudes toward Transitional Justice in Colombia", Conflict Management and Peace Science, Vol. 35, No. 6, 2018, p. 669.

193 Ibid., pp. 669-670.

194 Guy Grossman, Devorah Manekin and Dan Miodownik, "The Political Legacies of Combat: Attitudes toward War and Peace Among Israeli Ex-Combatants", International Organization, Vol. 69, No. 4, 2015, p. 1003.

195 S. Zukerman Daly, above note 192, p. 670.

196 See Kieran McEvoy and Heather Conway, "The Dead, the Law, and the Politics of the Past", Journal of Law and Society, Vol. 31, No. 4, 2004. 
remedies victims' harm, but also allows for the reintegration of those responsible. NSAGs as responsible actors can make an important contribution to acknowledging and alleviating victims' suffering. While the scope of the obligation to make reparations in international law for NSAGs remains debateable, such measures are practiced by NSAGs, but can vary in motivation and extent. A hierarchy of reparation obligations can reflect the different capacity of NSAGs to contribute to redressing the harm they have caused during conflict, alongside States' obligations to ensure reparation programmes for all victims. In such situations, remedying violations through reparations can take on the ideological flavour of the NSAG in terms of practicing its political agenda and governance, as well as offering some practical benefits of community support and image restoration to the armed group. Challenges remain in getting such groups to remedy the harm caused to the "other side", but in post-conflict societies there is clearly scope for this, as demonstrated by the work of the JEP in Colombia. During conflict, NSAGs' codes of conduct or other regulations could include norms on reparation or even remedies for breaches of the Deeds of Commitment used by Geneva Call. ${ }^{197}$

Reparations provide a way for victims, communities and humanitarian actors to engage NSAGs in reflecting on their actions and encourage nonrepetition of violations. In terms of facilitating accountability, reparations go beyond the finding of responsibility to the procedural aspect of answerability, 198 in hearing NSAGs give an explanation for their actions to those affected by them. The vernacular of reparations can enable armed groups to morally and politically articulate values, demonstrate leadership within the political communities for whom they claim to speak, normalize their social reintegration and reinforce norms of accountability. Ultimately reparations provide a medium for armed actors to struggle for societal transformation beyond the barrel of a gun, by making efforts to remedy their own wrongdoing.

197 See Ezequiel Heffes, "Responsible Groups: Reparations and Compliance in Non-International Armed Conflicts", Journal of Human Rights Practice, forthcoming.

198 K. Fortin, above note 10, p. 161. 